\title{
SOSIALISASI PENANGANAN KEGAGALAN RESIKO PENGOLAHAN AIR MINUM ISI ULANG DI KECAMATAN GUNUNG ANYAR SURABAYA
}

\author{
Euis Nurul Hidayah'1), Okik Hendriyanto Cahyonugroho'), Gabriela Veronica2) \\ 1)Program Studi Teknik Lingkungan, Fakultas Teknik, Universitas Pembangunan Nasional “Veteran” Jawa Timur, Indonesia \\ ${ }^{2)}$ Divisi Kesehatan dan Keselamatan Kerja, PT. Smart Tbk Jakarta, Indonesia \\ Corresponding author : Euis Nurul Hidayah \\ E-mail : euisnh.tl@upnjatim.ac.id
}

Diterima 8 April 2020, Disetujui 18 April 2020

\begin{abstract}
ABSTRAK
Adanya peluang bagi banyak industri untuk membuka depot air minum isi ulang (DAMIU), khususnya di Kecamatan Gunung Anyar, Surabaya. Isu yang muncul saat ini adalah rendahnya jaminan kualitas terhadap air minum isi ulang (AMIU) yang dihasilkan DAMIU. Jumlah koliform yang semakin besar menunjukkan kemungkinan bakteri patogen yang hidup di air yang terkontaminasi pencemaran. Meninjau permasalahan tersebut, maka kegiatan pengabdian masyarakat dilakukan dengan tujuan untuk menginformasikan kepada pengusaha DAMIU di Kecamatan Gunung Anyar tentang hasil pendataan teknologi pengolahan AMIU yang digunakan, menginformasikan hasil kualitas AMIU dari masing-masing DAMIU, menginformasikan risiko penyebab yang mempengaruhi kualitas AMIU dan memberikan rekomendasi upaya mengurangi risiko kegagalan produksi AMIU kepada pengusaha DAMIU. Sejumlah DAMIU menggunakan teknologi sinar UV sebesar 16 depot, teknologi sinar UVOzone sebesar 5 depot, teknologi RO sebesar 1 depot, sedangkan terdapat 1 depot tidak menggunakan teknologi desinfeksi. Analisa dari kegagalan kualitas air minum isi ulang pada parameter mikrobiologis (total koliform dan Eschericia coli). Risiko penyebabnya adalah karena sumber daya manusia, sumber air baku, metode, sarana dan prasaran, pengawasan dan evaluasi. Oleh karena itu perlu diberikan rekomendasi untuk mengurangi risiko kegagalan parameter mikrobiologis melalui waktu kontak UV atau Ozon minimal 4 menit, monitoring rutin perawatan unit pengolahan, menyusun standar operasional prosedur.
\end{abstract}

Kata kunci: air minum isi ulang; risiko; eschericia coli; total koliform; desinfeksi.

\begin{abstract}
There are opportunities for many industries to open refill drinking water stores (RDWS), especially in Gunung Anyar District, Surabaya. Some issues have been arised recently, such as issue of low quality assurance of drinking water produced by RDWS. The greater number of coliforms indicates the possibility of pathogenic bacteria that live in contaminated water. Reviewing these problems, community service activities were carried out with the aim of informing to RDWS owner in Gunung Anyar District about the results of data collection on RDW processing technology used, informing the results of RDW quality from each RDWS, informing the risk of causes affecting RDW quality and providing recommendations to reduce the failurd risk of RDW production to RDWS owner. Regarding disinfection technology, about 16 stores applied ultraviolet technology, UV-Ozone was used by stores, and the remain used RO technolog. Analysis of the failure of refill drinking water quality on microbiology parameters (total coliform and Eschericia coli). Those risk were arised due to human resources, raw water sources, methods, facilities and infrastructure, monitoring and evaluation. Therefore it is necessary to provide recommendations to reduce the risk of failure of microbiologyl parameters through UV or Ozone contact time of at least 4 minutes, routine monitoring of treatment units, preparing procedure operational standard.
\end{abstract}

Keywords: refill drinking water; risk; eschericia coli; total coliform; disinfection.

\section{PENDAHULUAN}

Setiap tahun laju pertumbuhan penduduk cukup tinggi sehingga menyebabkan peningkatan kebutuhan pelayanan air minum (Yudo dan Rahardjo, 2005). Badan Pusat Statistik Kota Surabaya menyebutkan bahwa jumlah penduduk di Surabaya tahun 2015 sebanyak 2.848 .583 dengan laju pertumbuhan penduduk $0,52 \%$ setiap tahunnya. Kondisi tersebut menjadi peluang bagi banyak industri untuk membuka depot air minum isi ulang (DAMIU). Kecamatan Gunung Anyar berpotensi 
dalam pemasaran air minum isi ulang di kota Surabaya karena memiliki jumlah penduduk pada tahun 2013 yaitu 53.476 dengan luas wilayah sekitar $962 \mathrm{Ha}$ dengan pertumbuhan ekonomi sebesar 5,60\% pada tahun 2010 (Badan Pusat Statistik, 2020).

Air minum isi ulang (AMIU) menawarkan harga lebih murah dibandingkan air minum dalam kemasan (Pradana dan Marsono,2013). Standar baku mutu air isi ulang terdapat pada Peraturan Menteri Kesehatan RI Nomor 492/Menkes/Per/IV/2010 tentang Persyaratan Kualitas Air Minum. Produk air minum isi ulang yang dikonsumsi masyarakat harus memenuhi standar baku mutu tersebut. Pendirian DAMIU diatur dalam Keputusan Menteri Perindustrian dan Perdagangan RI Nomor 65/MPP/Kep/10/2004 tentang Persyaratan Teknis Depot Air Minum dan Perdagangannya. Isu yang muncul saat ini adalah rendahnya jaminan kualitas terhadap air minum yang dihasilkan DAMIU. Dengan demikian kualitas air minum isi ulang masih perlu terus dikaji dalam rangka pengamanan kualitas yang sangat mempengaruhi derajat kesehatan masyarakat (Dewanti dan Sulistyorini, 2017

Sejumlah informasi menunjukkan kualitas berapa DAMIU dengan kualitas air minum isi ulang di Sukolilo mengandung total coliform melebihi batas baku mutu (Marpaung dan Marsono,2013). Jumlah coliform yang semakin besar menunjukkan kemungkinan bakteri pathogen yang hidup di air yang terkontaminasi pencemaran. Meninjau permasalahan tersebut, maka perlu dilakukan sosialisasi tentang baku mutu pada kualitas AMIU, upaya pengolahan AMIU dan rekomendasi untuk mengurangai kegagalan produksi AMIU dengan menerapkan metode Failure Mode and Effect Analysis (FMEA). Penerapan FMEA dapat memperkecil risiko terjadinya kegagalan dengan cara mempersiapkan sistem yang baik dan lebih memperhatikan hal - hal yang dapat berpotensi menyebabkan kegagalan (Stamatis, 1995).

Kegiatan pengabdian masyarakat yang dilakukan bertujuan untuk menginformasikan kepada pengusaha DAMIU tentang thasil pendataan teknologi pengolahan AMIU yang digunakan di Kecamatan Gunung Anyar, menginformasikan hasil kualitas AMIU dari masing-masing DAMIU, menginformasikan risiko penyebab yang mempengaruhi kualitas AMIU di Kecamatan Gunung Anyar dan memberikan rekomendasi upaya mengurangi risiko kegagalan produksi AMIU kepada pengusaha DAMIU di Kecamatan Gunung Anyar.

\section{METODE PENELITIAN}

Pengabdian masyarakat ini merupakan jenis kegiatan penerapan hasil penelitian tentang kualitas AMIU yang dimiliki oleh 23 DAIMU di Kecamatan Gunung Anyar. Hasil penelitian disosialisasikan kepada para pengusaha DAIMU di Kecamatan Gunung Anyar, sekaligus diberikan rekomendasi terhadap penanganan terhadap risiko kegagalan produksi AMIU. Pengabdian masyarakat dilakukan selama 1 (satu) hari dengan urutan jadwal kegiatan: menyajikan hasil pendataan tentang teknologi pengolahan air yang dimiliki oleh pengusaha DAIMU, menjelaskan hasil analisa kualitas air yang telah disampling dan penyebab kegagalan proses pengolahan AMIU, memberikan rekomendasi terhadap penanganan terhadap risiko kegagalan produksi AMIU.

\section{HASIL DAN PEMBAHASAN \\ Teknologi Pengolahan AMIU}

Pada pengolahan air minum pada masing-masing depot melalui 2 proses utama yaitu proses filtrasi dan proses desinfeksi. Pada proses filtrasi, air baku dari tendon dialirkan ke filter pasir silika yang berfungsi menyaring partikel-partikel halus dari serta mengurangi tingkat kekeruhan air baku, Kemudian dilanjutkan dengan filtrasi dengan filter karbon aktif yang berfungsi menghilangkan polutan mikro seperti zat organik, bau, deterjen, senyawa phenol, serta menyerap logam berat. Selanjutnya air dialirkan ke filter catridge. Catridge memiliki ukuran yang bervariasi dari 1 mikron - 10 mikron.
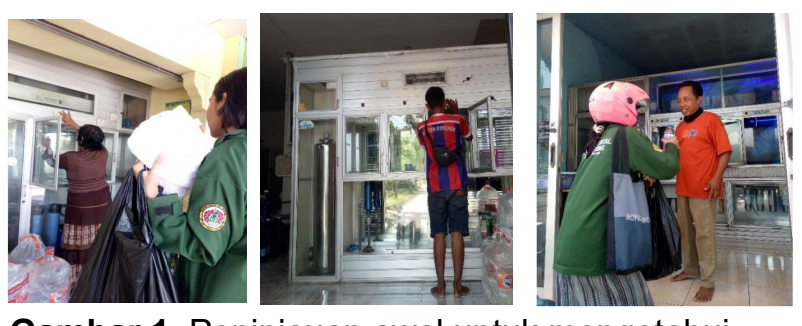

Gambar 1. Peninjauan awal untuk mengetahui teknologi pengolahan AMIU di berbagai DAMIU Kecamatan Gunung Anyar

Filter catridge berfungsi menghilangkan sisa partikel halus sehingga air menjadi lebih jernih. Setelah seluruh proses filtrasi selesai, dilanjutkan ke tahap desinfeksi, yaitu dengan menggunakan teknologi sinar ultraviolet (UV), ozonisasi, Reverse Osmosis (RO), maupun kombinasi dari beberapa teknologi tersebut. Proses desinfeksi berfungsi untuk membunuh bakteri pathogen. Selanjutnya air masuk kedalam proses pengemasan yaitu pengisian galon konsumen yang telah disterilisasi dan ditutup rapat. 
Berdasarkan hasil survei, terdapat 23 depot air minum isi ulang dengan menggunakan 3 jenis teknologi desinfeksi, yaitu sinar ultraviolet (UV), sinar UV-Ozone, dan Reverse Osmosis (RO). Data jumlah DAMIU menggunakan teknologi sinar UV sebesar 16 depot, untuk teknologi sinar UV-Ozone sebesar 5 depot, untuk teknologi RO sebesar 1 depot, sedangkan terdapat 1 depot tidak menggunakan teknologi desinfeksi, seperti ditampilkan pada Gambar 1 diatas. Untuk sumber air baku yang digunakan, berdasarkan hasil survei diperoleh 15 depot menggunakan air baku berasal dari air pengunungan Prigen, 7 depot berasal dari air pegunungan Trawas, dan dan 1 depot berasal dari air pengunungan Pacet.

\section{Analisa kualitas DAMIU}

Analisa $\mathrm{pH}$ digunakan untuk mengukur nilai derajat keasaman yang menunjukkan interaksi ion hydrogen dalam air yang mempengaruhi parameter lain seperti suhu, oksigen terlarut, aktivitas mikroorganisme, dan lain-lain. Nilai pH DAMIU di inlet pada rentang 6.7- 7.7 dan setelah pengolahan, nilai $\mathrm{pH}$ mencapai rentang 6.9-7.4, dan kualitas air dengan parameter $\mathrm{pH}$ memenuhi standar baku mutu Permenkes RI No.492/MENKES/PER/IV/2010, yaitu pH 6.58.5. Analisa kekeruhan menunjukkan parameter fisika air minum, di inlet pada rentang 0.15-1.02 NTU dan di outlet mencapai 0.08-1.00 NTU, dan kekeruhan telah memenuhi standar baku muta < 5 NTU. Analisa total dissolved solid (TDS) atau total padatan terlarut menunjukkan nilai $100-160 \mathrm{mg} / \mathrm{L}$ di inlet dan mencapai $50-130 \mathrm{mg} / \mathrm{L}$ di outlet, dan nilai tersebut telah memenuhi standar baku mutu TDS, kurang dari $500 \mathrm{mg} / \mathrm{L}$.

Analisa total koliform menunjukkan indikator adanya mikroba dalam air minum, diperoleh nilai total koliform 22/100mL-240/100 $\mathrm{mL}$ di inlet dan mencapai penurunan menjadi 045/100 mL. Jika mengacu pada standar baku mutu nilai total koliform adalah $0 / 100 \mathrm{~mL}$, maka hal ini menunjukkan bahwa ada DAMIU yang belum memenuhi standar baku mutu. Analisa bakteri Eschericia coli menunjukkan indikator tercemarnya air minum oleh feses atau tinja manusia yang bersifat enteropatogenik atau toksigenik yang berisiko langsung menyebabkan penyakit diare pada manusia. Nilai Eschericia coli menunjukkan angka 15/100 $\mathrm{mL}$ - 46/100 mL di inlet, dan setelah pengolahn diperoleh nilai Eschericia coli sebesar 0/100 mL - 18/100 mL. Jika mengacu pada standar baku mutu nilai Eschericia coli adalah 0/100 mL, maka hal ini menunjukkan bahwa ada DAMIU yang belum memenuhi standar baku mutu.
Beberapa risiko penyebab yang mempengaruhi kualitas AMIU di Kecamatan Gunung Anyar terdiri dari beberapa komponen antara lain:

1. Sumber Daya Manusia

Penjamah atau petugas yang melayani konsumen dalam pengisian air minum isi ulang belum memiliki wawasan yang cukup mengenai peraturan undangundang yang mengatur depot air minum isi ulang.

2. Sumber Air Baku

Menurut Peraturan Menteri Kesehatan RI No. 32 tahun 2017 kualitas air baku yang digunakan depot harus memenuhi persyaratan air untuk keperluan hygiene sanitasi dengan syarat fisik, kimia, dan mikrobiologis maupun radioaktivitas.

3. Metode

Menurut Peraturan Perindustrian dan Perdagangan No. 651/MPP/Kep/10/12004 tentang Persyaratan Teknis Depot Air Minum menetapkan bahwa SOP (Standar Operasional Prosedur) dalam melaksanakan proses pengolahan air minum isi ulang harus dimiliki setiap depot air minum Kecamatan Gunung Anyar serta melakukan uji laboratorium minimal 1 bulan sekali untuk parameter fisik, 3 bulan sekali untuk parameter kimiawi dan 6 bulan sekali untuk parameter mikrobiologis agar memastikan kualitas air hasil olahan selalu memenuhi baku mutu.

4. Sarana dan Prasarana
Berdasarkan Peraturan Menteri
Perindustrian dan Perdagangan
No.651/MPP/Kep/10/2004 menjelaskan tentang pengolahan air minum isi ulang meliputi penampungan air baku, filtrasi (prefilter,karbon filter, catridge filter), alat desinfeksi, dan pengisian.

5. Pengawasan dan Evaluasi

Berdasarkan Menteri Kesehatan No. 907 tahun 2002, pelaksanaan pengawasan kualitas air minum dengan ketentuan pemeriksaan kimiawi dan bakteriologis untuk air baku setiap 3 bulan sekali dan air minum isi ulang setiap sebulan sekali. Pengawasan yang tidak dilakukan secara rutin akan berdampak pada kualitas air minum isi ulang tidak dapat terkontrol dengan baik.

\section{Rekomendasi}

Persepsi masyarakat di Kecamatan Gunung Anyar terhadap AMIU menunjukkan bahwa penggunaan AMIU adalah sebagai sumber air layak minum, yang langsung diminum, artinya masyarakat mempercayakan kualitas air minum isi ulang sebagai air layak 
minum. Persepsi masyarakat menyatakan bahwa AMIU cukup aman untuk kesehatan walaupun dikonsumsi untuk jangka panjang. Namun, masyarakat merasakan adanya kegagalan kualitas pada air minum isi ulang, yaitu kegagalan kualitas AMIU pada parameter mikrobiologis. Masyakarat menganggap sterilisasi galon cukup baik, namun dikarenakan sebagian masyarakat merasakan adanya kegagalan pada sterilisasi galon maka tetap harus ditinjau kembali.

Berdasarkan hasil analisa kualitas AMIU, analisa risiko kegagalan produksi AMIU, dan persepsi masyarakat terhadap AMIU, maka berikut ini adalah rekomendasi yang diberikan kepada para pemilik / pengusaha / pengelola DAMIU Kecamatan Gununganyar :

1. Rekomendasi penanganan dari kegagalan kualitas air minum isi ulang pada parameter mikobiologis (total koliform dan Eschericia coli) yaitu minimal waktu kontak sinar UV dengan air baku minimal 4 detik dengan pengoperasian alat UV selama jam kerja depot air minum isi ulang, minimal waktu kontak alat ozon dengan air baku minimal 4 menit dengan pengoperasian alat ozon selama jam kerja depot air minum isi ulang, serta melakukan penggantian alat UV sesuai masa pakai atau kadaluarsa alat.

2. Rekomendasi teknologi desinfeksi yang paling efektif berdasarkan hasil uji laboratorium parameter mikrobiologis adalah dengan Reverse Osmosis (RO)

3. Melakukan monitoring kualitas dengan uji laboratorium secara berkala sesuai Peraturan Menteri Kesehatan No. 492 tahun 2010 agar kualitas air minum isi ulang dapat dipertahankan dan ditingkatkan kualitasnya

4. Melakukan perawatan unit pengolahan air minum isi ulang dengan memperhatikan kondisi dan masa pakai atau kadaluarsa unit agar dapat melakukan pembersihan serta penggantian alat sesuai peraturan.

5. Melakukan uji kualitas air baku maupun air olahan dengan alat terakreditasi yang dapat menguji fisik air (seperti kekeruhan, TDS, dan $\mathrm{pH}$ ) sehingga pemilik dapat menolak produsen air baku yang tidak memenuhi syarat.

6. Memperhatikan kebersihan atau sanitasi petugas maupun alat pengisian air minum sesuai Peraturan

Perdagangan dan Perindustrian No. 651 tahun 2004 agar dapat mengurangi risiko air hasil olahan terkontaminasi partikel pathogen yang dapat merugikan konsumen.

7. Membuat dan memiliki Standar Operating Procedure (SOP) yang dilaksanakan petugas yang diletakkan di tempat yang mudah dibaca serta melakukan pengawasan internal terhadap kepatuhan petugas terhadap SOP minimal 3 (tiga) bulan sekali.

Selain itu diperlukan perhatian dan upaya dari Pemerintah / Dinas Kesehatan / Puskesmas untuk melakukan hal-hal berikut ini:

1. Memberikan kebijakan terkait standar pemeliharaan unit pengolahan air minum isi ulang serta memberikan sanksi tegas terhadap setiap pelanggaran sehingga kualitas air minum hasil produksi lebih terjamin.

2. Memberikan pelatihan bersertifikat oleh Dinas Kesehatan sesuai Peraturan Menteri Kesehatan No. 43 tahun 2014 kepada seluruh petugas depot di Kecamatan Gununganyar agar dapat lebih memahami pengelolaan DAMIU sesuai peraturan.

3. Mengembangkan koordinasi antar instansi yang terintegrasi serta melibatkan seluruh pemilik DAMIU melalui Asosiasi Pengusaha Depot Air Minum (ASPADA) sebagai organisasi yang bergerak dibidang usaha AMIU dalam hal pengawasan DAMIU di Kecamatan Gununganyar

Selain itu, konsumen atau masyarakat diharapkan membantu pemerintah dalam hal pengawasan sebagai sebagai kontrol sosial terhadap kualitas air minum isi ulang yang dirasa belum memenuhi standar baku mutu yang telah ditetapkan. Masyarakat yang mengkonsumsi AMIU perlu untuk memasak terlebih dahulu sebelum dikonsumsi, meskipun hasil uji laboratorium menunjukkan tidak adanya kontaminasi bakteri, agar kualitas air minum isi ulang bebas dari kontaminan lebih terjamin.

\section{SIMPULAN DAN SARAN}

Berdasarkan informasi dari para pengusaha DAMIU, maka diperoleh kesimpulan bahwa dalam proses pengolahan air minum isi ulang ditemukan beberapa faktor yang menimbulkan risiko kegagalan kualitas air hasil produksi kurangnya pengelolaan kualitas unit pengolahan, pengetahuan pemilik atau pengelola depot air minum isi ulang masih terbatas, minimnya sterilisasi pengemasan air, serta pengawasan langsung baik dari pemilik atau pengelola depot maupun pemerintah terkait aspek-aspek pada usaha air minum isi ulang. Sejumlah rekomendasi telah diberikan kepada para pengusaha DAMIU untuk ditindaklanjuti atau diimplementasikan.

Saran terhadap para pengusaha DAMIU dan kegiatan pengabdian masayarakat selanjutnya adalah memantau implementasi dari rekomendasikan yang diberikan, dan perlu dilakukan pendampingan untuk menyusun SOP 
sesuai teknologi pengolahan AMIU yang dimiliki oleh masing-masing pengusaha DAMIU.

\section{DAFTAR RUJUKAN}

Badan Pusat Statistik, (2020), Kota Surabaya Dalam Angka 2020, Penyediaan Data untuk Perencanaan Pembangunan.

Dewanti, Ria A., dan Sulistyorini, L., (2017). "Analisis Kualitas Bakteriologis Air Minum Isi Ulang di Kelurahan Sememi, Kecamatan Benowo", The Indonesian Journal of Public Health. 12(1). 39-50.

Marpaung dan Marsono., (2013), "Uji Kualitas Air Minum Isi Ulang di Kecamatan Sukolilo Surabaya Ditinjau dari Perilaku dan Pemeliharaan Alat", Jurnal Teknik Pomits ITS. 2(2), 24-31.

Pradana dan Marsono, (2013), “Uji Kualitas Air Minum Isi Ulang Di Kecamatan Sukodono, Sidoarjo Ditinjau Dari Perilaku dan Pemeliharaan Alat", Jurnal Teknik Pomits ITS. 2(2).

Stamatis, D. H. (1995). Failure Mode and Effect Analysis : FMEA from Theory to Execution Milwaukee : ASQC Quality Press

Yudo, S., dan Raharjo, P. N., (2005), "Evaluasi Teknologi Air Minum Isi Ulang di DKI Jakarta", JAI, 1(3). 